\title{
Az antitestmediált rejekció diagnosztikája és kezelése gyakorlatunkban
}

\author{
P. Szabó Réka dr. ${ }^{1,7}$ - Amna Jousaf Hashmi ${ }^{2}$ - Kóti Nikolett ${ }^{2}$ \\ Szilvási Anikó ${ }^{3}$ - Bidiga László dr. ${ }^{4}$. Kardos László dr. ${ }^{5}$ \\ Zsom Lajos dr. ${ }^{6}$ - Balla József dr. ${ }^{7}$ - Nemes Balázs dr. ${ }^{1}$ \\ ${ }^{1}$ Debreceni Egyetem, Általános Orvostudományi Kar, Sebészeti Intézet, \\ Szervtranszplantációs Nem Önálló Tanszék, Debrecen \\ ${ }^{2}$ Debreceni Egyetem, Általános Orvostudományi Kar, Debrecen \\ ${ }^{3}$ Országos Vérellátó Szolgálat, Transzplantációs Immungenetikai Laboratórium, Budapest \\ ${ }^{4}$ Debreceni Egyetem, Általános Orvostudományi Kar, Pathológiai Intézet, Debrecen \\ ${ }^{5}$ Debreceni Egyetem, Általános Orvostudományi Kar, Infektológiai Klinika, Debrecen \\ ${ }^{6}$ Fresenius Medical Care Dialízis Központ, Cegléd \\ ${ }^{7}$ Debreceni Egyetem, Általános Orvostudományi Kar, Belgyógyászati Intézet, Debrecen
}

Bevezetés: Az antitest közvetítette kilökődés a graftvesztés gyakori oka a vesetranszplantáltak körében.

Célkitüzés: Célul tűztük ki, hogy ismertetjük a centrumunkban biopsziával igazolt humorális kilökődéssel rendelkező betegeknek a kezelésre (standard kezelés: plazmaferézis, immunglobulin, rituximab) adott válaszát, valamint hogy vizsgáljuk a proteinuria grafttúlélésre kifejtett hatását és azt, hogy ezt a DSA-tól függetlenül teszi-e. Vizsgáltuk az eGFR-, a DSA-MFI-értéknek az antirejekciós terápia hatására bekövetkező változásait is.

Módszer: 85 beteg retrospektív analízisét végeztük el. A szövettani elemzésben a Banff-klasszifikációt vettük alapul. A csoportok összehasonlításához kategorikus változók esetén a Fisher-féle egzakt próbát, folyamatos változók esetén a Kruskal-Wallis-próbát használtuk.

Eredmények: A biopsziával igazolt humorális rejekciós csoportba (ABMR-csoport) 19, a DSA-pozitív csoportba 14, a DSA-negatív csoportba 52 beteget választottunk be. A DSA-érték az ABMR-csoportban 61,16\%-kal csökkent, a DSA-pozitív csoportban 42,86\%-kal redukálódott (Fisher-féle egzakt: p = 0,1). Az ABMR-csoportban 9 betegnek a jelentős, 4-nek a nephroticus mértékú proteinuriája csökkenthető volt (az ABMR-csoport 68\%-a). A legjobb grafttúlélés a legalacsonyabb fehérjeürítésnél adódott. Az antirejekciós terápiát követően készült biopsziákban: a glomerulitis, az interstitialis gyulladás, az arteritis mértéke csökkent az antihumorális kezelés hatására, azonban krónikus elváltozások jelentek meg.

Következtetés: Az ABMR-csoportban az antirejekciós terápiát követően a fehérjeürítés monitorizálása javasolt, hiszen becsülhető vele a grafttúlélés.

Orv Hetil. 2021; 162(26): 1029-1037.

Kulcsszavak: grafttúlélés, donorspecifikus antitest, antitestmediált rejekció

\section{Management of antibody-mediated rejection after kidney transplantation in our clinical practice}

Introduction: Antibody-mediated rejection is a common cause of graft loss among kidney transplant recipients.

Objective: We aimed to describe the response of patients with biopsy-proven humoral rejection to treatment (standard treatment: plasmapheresis, immunoglobulin, rituximab) in our center. We also analyzed the effect of proteinuria on graft survival and whether this effect is independent of donor-specific antibodies (DSAs). Changes of eGFR and level of DSA following rejection treatment were examined.

Method: In this study, laboratory data of 85 patients were analysed. Histological analysis was based on the Banff classification. Fisher's exact test was used for statistical analysis, and Kruskal-Wallis test was used to compare patient groups per variable. 
Results: Data from 85 patients were processed retrospectively. 19 patients were selected for the biopsy-confirmed humoral rejection group (ABMR group), 14 for the DSA-positive group, and 52 for the DSA-negative group. DSA titer decreased by $61.16 \%$ in the ABMR group after treatment and by $42.86 \%$ in the DSA-positive group (Fisher's exact test: $\mathrm{p}=0.1)$. In the ABMR group, significant nephrotic proteinuria in 4 patients and severe proteinuria in 9 patients were reduced ( $68 \%$ of ABMR group). The patients with the lowest protein excretion had the best graft survival. In biopsies performed after antirejection therapy, the extent of glomerulitis, interstitial inflammation, arteritis decreased with antihumoral treatment, but chronic lesions appeared.

Conclusion: Following treatment of biopsy-proven ABMR, reduction of proteinuria predicts graft survival and should be monitored as an important factor-predicting prognosis.

Keywords: graft survival, donor-specific antibody, antibody-mediated rejection

P. Szabó R, Hashmi AJ, Kóti N, Szilvási A, Bidiga L, Kardos L, Zsom L, Balla J, Nemes B. [Management of antibody-mediated rejection after kidney transplantation in our clinical practice]. Orv Hetil. 2021; 162(26): 1029-1037.

(Beérkezett: 2021. március 30.; elfogadva: 2021. május 4.)

\section{Rövidítések}

$\mathrm{AA}=$ aldoszteronantagonista; $\mathrm{ABMR}=$ (antibody-mediated rejection) antitestmediált rejekció; $\mathrm{ACE}=$ (angiotensinconverting enzyme) angiotenzinkonvertáló enzim; ACR = (albumin-kreatinin ratio) albumin-kreatinin arány; $\mathrm{CDC}=$ (complement-dependent cytotoxicity) komplementdependens citotoxicitás; COVID-19 = (coronavirus disease 2019) koronavírus-betegség 2019; ELISA = (enzyme-linked immunosorbent assay) enzimhez kapcsolt immunszorbens-vizsgálat; DGF $=($ delayed graft function $)$ későn induló graftfunkció; DSA = donorspecifikus antitest; eGFR = (estimated GFR) becsült GFR; GFR = glomerulusfiltrációs ráta; HLA = humán leukocytaantigén; IFTA = interstitialis fibrosis tubularis atrophiával; IgG = immunglobulin-G; ivIG = intravénás immunglobulin; MFI $=$ (mean fluorescence intensity) átlagos fluoreszcenciaintenzitás; $\mathrm{mTOR}=($ mammalian target of rapamycin $)$ rapamicin-célfehérje emlősökben; MVI = microvascularis inflammatio; PTC $=$ peritubularis capillaritis; $\mathrm{rMAB}=$ rituximab; $\mathrm{SAB}=$ (single antigen bead) egyetlen antigéngyöngy; TCMR = ( $\mathrm{T}$ cell-mediated rejection) $\mathrm{T}$-sejt-mediált rejekció; TPCR = (total protein creatinine ratio) teljes protein-kreatinin arány

Veseátültetést követően a hosszú távú grafttúlélés javult az elmúlt 2 évtizedben, a HLA-ellenes donorspecifikus antitesttel (DSA) rendelkezőknek azonban kedvezőtlenebb a graftprognózisuk [1]. A diagnosztika fejlődése ellenére az antitestmediált rejekció (ABMR) a graftvesztés és a dialízisbe visszatérés leggyakoribb kóroki tényezője. Viglietti és munkacsoportja létrehozott egy dinamikus prognosztikus pontrendszert, amelynek segítségével becsülhető a grafttúlélés, mivel a kezelést követő szövettani értékeket is alkalmazza; a klinikai gyakorlatban nem terjedt el az ismételt biopsziák invazivitása miatt. Kiemelendő prediktív paraméterek: 1) a Banff-pontszám>0;2) a PTC pontszámának változása a terápia után; 3 ) az antiHLA-DSA-szint változása számolt pontrendszer alapján. Ezek alapján a betegek besorolhatók három csoportba: alacsony, közepes és magas rizikójú csoportokba, így jól becsülhető a grafttúlélés [2]. Az ABMR kialakulásában elsődleges szerepe van a recipiens immunrendszere és az allograft között közvetítő felületként funkcionáló endotheliumnak, pontosabban ez ezen expresszálódó antigéneknek és az ellenük irányuló ellenanyagoknak. Az alloantitestek patogén szerepének felismerése az 1960-as évekre nyúlik vissza, amikor összefüggést mutattak ki a komplementdependens citotoxicitás (CDC) módszerével kimutatható DSA-k és a hiperakut rejekció között. A módszer sok helyen máig a leghitelesebb bizonyító eszköznek (arany standard) számít. A CDC-módszert később az érzékenyebb, enzimhez kapcsolt immunszorbens-vizsgálat (ELISA) és áramlási citometriás módszerek követték, míg mára a DSA-k kimutatásában az úgynevezett 'single antigen beads' módszer $(\mathrm{SAB})$ vált a legelterjedtebbé (Luminex-SAB) a CDC-módszer mellett, illetve részben azt kiszorítva [3-6]. A SAB-módszer multiplex mérés, amelyben fluoreszcens gyöngyök felszínéhez kötötten közel 200 HLA segítségével történik az egyén alloantitest-repertoárjának meghatározása. A donorellenes antitestek lehetnek már meglévő, preformált antitestek, melyek hátterében immunizáló tényezők (korábbi transzfúziók, terhességek, korábbi szervátültetések) szerepelhetnek, vagy újonnan keletkező, ún. de novo antitestek, melyek többnyire a transzplantációt követően válnak detektálhatóvá [7-10].

A graft szövettani vizsgálata invazív, mégis arany standard a kilökődés diagnosztikájában, nem helyettesíthető más laboratóriumi vizsgálattal. A biopszia gyenge pontjai: a mintavételi technikából adódó esetleges nem informatív anyagmennyiség, a (rendszeres) ismétlés nem vagy csak erős indikációval biztosítható lehetősége és ebből adódóan a biopszia időpontjának jó időzítése (például ez adott a szívátültetésnél). Amennyiben a biopsziát túl korán vagy túl későn végzik, esetleg a vett minta nem megfelelő minőségű, úgy az eredmény is téves lehet. A biopsziák lehetnek protokollbiopsziák, melyben a mintavétel a beültetést követően megadott időben történik: fél évvel, egy évvel a transzplantációt követően, ez szervenként változó lehet - a szív esetében gyakoribb mintavé- 
telre is szükség van. A biopsziák másik csoportja az ún. indikáció (menedzsment)-biopsziák, melyeknél a DSAeredmény, a fehérjeürítés és a kreatininemelkedés alapján döntünk a mintavétel mellett. A Banff-klasszifikáció, mely kétévente revízióra kerül, egységesítette a transzplantált graftok szövettani leírását. A kilökődés különböző típusai: T-sejt-mediált (TCMR), borderline és antitestes. A Banff-klasszifikációban 1991 óta történt változtatásai közül kiemelendő a 2013. évi, amelybe a Cd4-negatív ABMR-forma is bekerült, és a 2017. évi, melyben a C4d-pozitivitás helyettesítheti a DSA-t [3-10]. A 2013. évi Banff-klasszifikációban használt akut/aktív ABMRcsoport klinikailag lehet akut, fellángolás vagy szubklinikai. Mindez a 2015. évi Banff-klasszifikációban is változatlan maradt, viszont az aktuális, 2017. évi Banff-klaszszifikáció alapján: aktív ABMR; a diagnózishoz mind a 3 szövettani kritérium teljesülése szükséges [3-10]. Morfológiailag igazolt heveny szövetkárosodás; egy vagy több a következőkből: 1) microvascularis inflammatio (MVI) (g>0 és vagy PTC>0) újonnan kialakuló vagy visszatérő glomerulonephritis hiányában, viszont akut TCMR, borderline kilökődés vagy fertőzés esetében a PTC $\geq 1$ mellé minimum $\mathrm{g} \geq 1$ szükséges; intimalis vagy transmuralis arteritis ( $\mathrm{v}>0)$; egyébbel nem magyarázható, heveny thromboticus microangiopathia; egyébbel nem magyarázható, heveny tubularis károsodás. 2) A közelmúltban lezajlott/zajló antitest-endothelsejt interakció bizonyítéka; l vagy több a következőkből: lineáris PTC C4d-pozitivitás (C4d++/+++ IF fagyasztott metszeten, C4d>0 IP paraffinos metszeten); legalább mérsékelt MVI ([g + PTC $] \geq 2)$ újonnan keletkező vagy viszszatérő glomerulonephritis hiányában, viszont akut Tsejt-mediált rejekció, borderline kilökődés vagy fertőzés esetében a PTC $\geq 2$ mellé minimum g $\geq 1$ szükséges; a gén transzkriptumok/osztályozók fokozott kifejeződése ABMR-rel társul (amennyiben hitelesítették). 3) DSA-k szerológiai bizonyítéka (DSA, HLA vagy egyéb). A C4dpozitivitás a gén transzkriptumok/osztályozók fokozott kifejeződésével együtt helyettesítheti a DSA-t. Az 1. és a 2. kritérium teljesülése esetében DSA-meghatározás javasolt (HLA-negatív esetekben non-HLA is). Krónikus aktív ABMR; a diagnózishoz mind a 3 kritérium teljesülése szükséges. 1. Morfológiailag igazolt krónikus szövetkárosodás; l vagy több a következőkből: transzplantációs glomerulopathia $(\mathrm{cg}>0)$ krónikus thromboticus microangiopathia, de novo vagy visszatérő glomerulonephritis hiányában, beleértve az EM-vizsgálattal igazolható eltéréseket is (cgla), melynek leírásában saját anyagunk mellett más centrumok hazai szerzőinek színvonalas közlésére is támaszkodhatunk; súlyos PTC bazálmembrán-rétegződés (elektronmikroszkópia szükséges); másként nem magyarázható, újdonképződött, artériákat érintő intimalis fúrósos; korábbi TCMR hiányában a scleroticus intimát infiltráló leukocyták krónikus ABMR-re utalnak [3-10]. A 2019. évi Banff-klasszifikáció a krónikus aktív formákat finomítja a T-sejtes kilökődés, a borderline és ABMR formákon belül, a molekulá- ris genetikai módszereket és a mesterséges intelligencia szerepét is taglalja. Az ABMR-rel kapcsolatban az MVI- $t$ hangsúlyozza. Bizonyított, hogy a DSA-val nem rendelkező betegekhez képest az MVI-vel rendelkezőknek jobb a grafttúlélésük, függetlenül a C4d-festődéstől. DSA-pozitív betegek többnyire többszörös transzplantáltak, gyakran C4d-pozitívak. A későn biopsziázott betegek esetében súlyos microvascularis inflammatio látható, gyakran IFTA-val. Érdekes azonban, hogy ezen esetekben nem volt különbség a HLA-ellenes DSA-val rendelkezők, illetve nem rendelkezők között a graft túlélésében $[10,11]$.

Roufosse és munkacsoportja 2018-ban publikálta a Banff-klasszifikációhoz adaptált irányelvet, mely a 2017es klasszifikációt hivatott érthetővé tenni. Az 1. táblázatban foglaltuk össze a Banff-laesio pontrendszerét, a rövidítéseket [12].

A HLA-ellenes antitestek mellett egyre nagyobb irodalmuk van a non-HLA-ellenanyagoknak, amelyek a betegek 10-40\%-ánál megjelenhetnek az antitestmediált folyamatokban [8-10]. Lefaucher és mtsai leírták, hogy a klinikailag manifesztálódó ABMR nélkül a már meglévő DSA-val rendelkező betegek grafttúlélése kedvezőtlenebb, egy évvel a transzplantáció után az eGFR-értékük alacsonyabb a DSA-val nem rendelkező betegekhez viszonyítva. Szintén Lefaucher és kutatói írták le elsóként, hogy a meglévő DSA-MFI>6000 érték felett - a 465-ös MFI-értékhez viszonyítva - százszorosa az ABMR-rizikónak [12-16].

A fehérjeürítés oka a transzplantált vesében számos kóroki tényezőre vezethető vissza, ezek közül a leggyakoribbak a visszatérő vagy új keletű glomerularis betegségek, HLA-ellenes antitest okozta károsodás, interstitialis fibrosis, tubularis atrophia, mTOR-inhibitor-mellékhatás [16]. A vesebetegség és a cardiovascularis kockázat becsléséhez az eGFR mellett nélkülözhetetlen a proteinuira, illetve az albuminuria megbízható vizsgálata is [17]. Az ACR (albumin-kreatinin arány) és a TPCR (teljes protein-kreatinin arány) vizsgálatára a leginkább a reggeli első vizeletmintából történő meghatározás javasolt [18]. A 24 órás mintából történt meghatározás lehetővé teszi a napi ürített albumin, illetve protein meghatározása mellett a gyújtés pontosságának (napi kreatininürítés) ellenőrzését. A microalbuminuria tartományában $(3<\mathrm{ACR}<30 \mathrm{mg} / \mathrm{mmol}, 15<\mathrm{TPCR}<45 \mathrm{mg} / \mathrm{mmol})$ az ACR alkalmazása javasolt (érzékenyebb), míg proteinuria (macroalbuminuria: $\mathrm{ACR}>30 \mathrm{mg} / \mathrm{mmol}$, TPCR $>45$ $\mathrm{mg} / \mathrm{mmol}$ ) esetén a TPCR használata javasolt (megbízhatóbb és lényegesen olcsóbb) [19-22]. A fehérjeürítés rendszeres ellenőrzése egyszerü, ismételhető, olcsó vizsgálat, a napi gyakorlatban kiválóan használható. Jól ismert, hogy a nagymértékü fehérjeürítés GFR-kategóriánként fokozza a betegek cardiovascularis rizikóját. Az immunszuppresszió mellett természetesen a konzervatív terápia elemeit is alkalmazzuk lehetőség szerint (például ACE-gátlók, sztatinok, AA) az összes betegnél a fehérjeürítés csökkentésére [23-26]. 
1. táblázat |A Banff-laesio-pontrendszer összegzése, küszöbértékek és gyakori rövidítések

\begin{tabular}{|c|c|c|c|c|c|}
\hline Banff-laesio-pontrendszer & Rövidítés & 0 & 1 & 2 & 3 \\
\hline Interstitialis gyulladás & $\mathrm{i}$ & $<10 \%$ & $10-25 \%$ & $26-50 \%$ & $>50$ \\
\hline Tubulitis & $\mathrm{t}$ & Nincs & $\begin{array}{l}1-4 / \text { tubulus keresztmetszeti/ } \\
10 \text { tubularis epithelsejt }\end{array}$ & $5-10$ & $\begin{array}{l}>10 \text { vagy fokális } \\
\text { tubularis membrán- } \\
\text { károsodás } i \geq 2\end{array}$ \\
\hline Intima arteritis & $\mathrm{v}$ & Nincs & $<25 \%$ lumencsökkenés & $\geq 25 \%$ lumencsökkenés & $\begin{array}{l}\text { Ttransmuralis és / } \\
\text { vagy fibrinoid } \\
\text { átépülés és media } \\
\text { simaizom nekrózis }\end{array}$ \\
\hline Glomerulitis & $\mathrm{g}$ & Nincs & $<25 \%$ & $25-75 \%$ & $>75 \%$ \\
\hline Peritubular capillaritis & PTC & $\begin{array}{l}\text { <3 fehérvér- } \\
\text { sejt/PTC }\end{array}$ & $\begin{array}{l}\geq 1 \text { fehérvérsejt } \geq 10 \% \\
\text { PTC-k 3-4/PTC }\end{array}$ & $\begin{array}{l}\geq 1 \text { fehérvérsejt } \geq 10 \% \\
5-10 / \text { PTC }\end{array}$ & $\begin{array}{l}\geq 1 \text { fehérvérsejt } \\
\geq 10 \% \\
>10 / \text { PTC }\end{array}$ \\
\hline $\mathrm{C} 4 \mathrm{~d}$ & $\mathrm{C} 4 \mathrm{~d}$ & Nincs & $<10 \%$ & $10-50 \%$ & $>50 \%$ \\
\hline Interstitialis fibrosis & $\mathrm{ci}$ & $\leq 5 \%$ & $6-25 \%$ & $26-50 \%$ & $>50 \%$ \\
\hline Tubularis atrophia & $\mathrm{ct}$ & Nincs & $\leq 25 \%$ & $26-50 \%$ & $>50 \%$ \\
\hline Vascularis fibrointima vastagodás & $\mathrm{cv}$ & Nincs & $\leq 25 \%$ & $26-50 \%$ & $>50 \%$ \\
\hline GBM kettős kontúr & $\mathrm{cg}$ & Nincs & $\begin{array}{l}\text { la: csak elektronmikroszkóppal } \\
\text { lb: } \leq 25 \% \text { fénymikroszkóp }\end{array}$ & $26-50 \%$ & $>50 \%$ \\
\hline Mesangialis mátrix expanzió & $\mathrm{mm}$ & Nincs & $\leq 25 \%$ & $26-50 \%$ & $>50 \%$ \\
\hline Arteriolaris hyalinosis & $\mathrm{ah}$ & Nincs & Enyhe-közepes fokú $\geq 1$ & Közepes-súlyos fokú >l & Súlyos fokú \\
\hline Arteriola hyalinosis vastagodás & aah & Nincs & Kerületi 1-nél kevesebb & $\geq 1$ & Körkörös \\
\hline Összes gyulladás & $\mathrm{ti}$ & $<10 \%$ & $10-25 \%$ & $26-50 \%$ & $>50 \%$ \\
\hline Gyulladás az IFTA-ban & i-IFTA & $<10 \%$ & $10-25 \%$ & $26-50 \%$ & $>50 \%$ \\
\hline
\end{tabular}

GBM = glomerularis bazálmembrán; IFTA = interstitialis fibrosis tubularis atrophiával; PTC = peritubularis capillaritis

Roufosse és mtsai alapján (Transplantation 2018; 102: 1800) [12]

\section{Célkitüzés}

Célul tûztük ki, hogy vizsgáljuk a proteinuria grafttúlélésre kifejtett hatását, illetve hogy ez a DSA-tól független-e. Vizsgáltuk az eGFR-, DSA-MFI-értéknek az antirejekciós terápia hatására bekövetkező változásait is. Ahol rendelkezésre állt, elemeztük az antirejekciós terápia utáni szövettani változásokat. Az antirejekciós kezelést követően a rebiopsziás mintákban elemeztük a szövettani változásokat.

\section{Módszer}

A vesebiopszia szövettani véleményezése a Banff-kritériumok alapján történt. Tekintve, hogy a szövettani mintavételek 2013 és 2020 között készültek, a szövettani leletezés a 2013-as, 2017-es Banff-rendszer alapján készült. $\mathrm{Az}$ adatokat a középérték \pm standard deviációval adtuk meg folyamatos változók és számszerüsítve (százalékosan) kategorikus változók esetén. A statisztikai elemzéseket khi-négyzet/Fisher-féle egzakt, Mann-WhitneyWilcoxon- és Kruskal-Wallis-próbákkal, valamint varianciaanalízissel végeztük. Szignifikánsnak vettük a kapott eredményt, ha a p értéke $<0,05$ volt. Az analíziseket SPSS statisztikai szoftverrel végeztük ( 25.0 verzió; IBM,
Armonk, NY, Amerikai Egyesült Államok ). A kumulatív grafttúlélés jellemzéséhez Kaplan-Meier-görbéket, a túlélési viszonyok nyers összehasonlításához log-rank tesztet, korrigált elemzéséhez Cox-féle regressziót használtunk. A standard antirejekciós kezelés 5 plazmaferézisből állt, ivIG 3 egymás utáni alkalommal történő adását, 500 mg metilprednizolonbolust (3 napig) és egy vagy több alkalommal rituximab $\left(375 \mathrm{mg} /\right.$ testfelszín $\left./ \mathrm{m}^{2}\right)$ adását jelentette [27]. Három csoportot alkottunk: 1) a biopsziával igazolt antitestmediált rejekcióval rendelkezők (ABMR-csoport). Az ABMR-diagnózis felállítása 2013 és 2020 között történt. 2) A HLA-ellenes DSA-val rendelkező, stabil graftfunkciós betegek (DSA-pozitív csoport). 3) A harmadik „referenciacsoportunkat” a DSAval nem rendelkező, stabil graftmúködésű betegek alkották (DSA-negatív csoport), akiket centrumunkban gondozunk.

\section{Eredmények}

Centrumunkban 1991 és 2020 között 1171 veseátültetést végeztek, ebből 2013 és 2020 között 343 veseátültetés történt. Ezek közül 2013 és 2020 között az akut ABMR diagnózisát 19 betegnél állítottuk fel. Összesen 85 beteg adatait elemeztük. 52 beteg nem rendelkezett 
2. táblázat $\mid$ Az ABMR-csoport, a DSA-pozitív csoport, a DSA-negatív csoport kor, nem szerinti eloszlása, az indukciós terápia típusai, az alkalmazott antirejekciós terápiák

\begin{tabular}{|c|c|c|c|c|}
\hline Betegcsoportok & $\begin{array}{l}\text { ABMR-csoport } \\
(\mathrm{n}=19)\end{array}$ & $\begin{array}{l}\text { DSA-pozitív csoport } \\
(\mathrm{n}=14)\end{array}$ & $\begin{array}{l}\text { DSA-negatív } \\
\text { csoport }(\mathrm{n}=52)\end{array}$ & Statisztika \\
\hline \multicolumn{5}{|l|}{ Életkor } \\
\hline (év) & $41,63(S D=16,65)$ & $39,64(\mathrm{SD}=19,61)$ & $49,76(\mathrm{SD}=2,61)$ & ANOVA: $\mathrm{p}=0,0275$ \\
\hline \multicolumn{5}{|l|}{$\mathrm{Nem}$} \\
\hline Nő & $6(31,58 \%)$ & $3(21,43 \%)$ & $32(37,65 \%)$ & \multirow[t]{2}{*}{ Fisher-féle egzakt teszt: 0,287} \\
\hline Férfi & $13(68,42 \%)$ & $11(78,57 \%)$ & $53(62,35 \%)$ & \\
\hline \multicolumn{5}{|l|}{ Indukciós terápia } \\
\hline Nem részesült indukciós terápiában & $2(10,53 \%)$ & $8(57,14 \%)$ & $28(53,85 \%)$ & \multirow[t]{3}{*}{ Fisher-féle egzakt teszt: 0,006} \\
\hline ATG & $13(68,42 \%)$ & $5(35,71 \%)$ & $15(28,85 \%)$ & \\
\hline Baziliximab & $4(21,05 \%)$ & $1(7,14 \%)$ & $9(17,31 \%)$ & \\
\hline DGF & $6(31,58)$ & 0 & 0 & Fisher-féle egzakt teszt: $\mathrm{t}=0,027$ \\
\hline \multicolumn{5}{|l|}{ Az alkalmazott antirejekciós kezelés típusa } \\
\hline Plazmaferézis + ivIG + rituximab & $13(68 \%)$ & - & - & \\
\hline Alemtuzumab & $1(5,56 \%)$ & - & - & \\
\hline Egyéb & $5(26 \%)$ & - & - & \\
\hline
\end{tabular}

$\mathrm{ABMR}=$ antitestmediált rejekció; ANOVA = varianciaanalízis; ATG = antithymocyta-globulin; DGF = későn induló graftfunkció; DSA = donorspecifikus antitest; ivIG = intravénás immunglobulin; SD = standard deviáció

DSA-val - ezt a csoportot tekintettük ún. kontrollcsoportnak -, nekik stabil graftfunkciójuk volt, náluk vártuk a legkedvezőbb grafttúlélést. A DSA-pozitív csoportban 14 beteg rendelkezett DSA-val rejekció nélkül, stabil graftfunkcióval. 19 betegnél szövettanilag igazolódott az ABMR. A transzplantáció és az ABMR-diagnózis közötti idő mediánja 16,5 hónap volt (interkvartilis terjedelem: 1,2-32,3 hónap). Összehasonlítottuk a csoportok demográfiai adatait és kumulatív grafttúlélését. Az átlagos követési idő 12,32 év volt. A 2. táblázat összegzi a három csoport alapvető demográfiai és transzplantációspecifikus paramétereit (életkor, nemek eloszlása, későn induló graftfunkció [DGF] előfordulása, az indukciós terápia típusa). Preformált (perzisztáló) DSA az ABMRcsoportban: 52,65\%, de novo DSA: 31,58\%; a DSA-pozitív csoportban csak de novo DSA-t mértünk (Fisher-teszt: $\mathrm{p}<0,001)$. A detektált DSA 2-es osztályú HLA ellen irányult 68,42\%-ban az ABMR-csoportban, 92,31\%-ban a DSA-pozitív csoportban. A HLA-egyezés megoszlása az alábbi volt: $3(26,32 \%)$ vagy $4(52,63 \%)$ (Fisher-teszt: $\mathrm{p}=0,172)$. A DSA-pozitív betegek 42,2\%-ának DSAMFI-értéke kevesebb mint 6000-nek adódott (1. ábra). $\mathrm{Az}$ 1. ábrán látható, hogy az ABMR-csoportban nagyobb volt azon betegek aránya, akik 3000-6000 MFI közötti értékkel rendelkeztek, 6000 fölötti MFI-értékkel azonban csak az ABMR-csoportban volt betegünk. DGF csak az ABMR-csoportban fordult elö: 6 esetben $(31,58 \%$, Fisher-teszt: $\mathrm{p}=0,0227)$. Az indukciós terápia az esetek 68,42\%-ában timoglobulinból, 21,05\%-ában baziliximabból állt az ABMR-csoportban, míg a DSApozitív csoportban: $35,71 \%$ timoglubulin, 7,14\% baziliximab (Fisher-teszt: $\mathrm{p}=0,006)$. Az antirejekciós kezelés részeként 3 beteg nem kapta meg a rituximabkezelést infektív szövődmények miatt. A fenntartó immunszuppresszív terápia miokofenolát-mofetil-, takrolimuszalapú volt (többnyire 6-10 ng/ml), szteroiddal kiegészítve. 1 beteg részesült alemtuzumabterápiában a standard plazmaferézis + ivIG + rituximab kezelést követően. Az eGFR változásainak elemzésekor a referenciaként vizsgált DSA-negatív csoportban a legjobbak a kiindulási eGFR-értékek. Az antirejekciós kezelést követően javulás volt észlelhető az ABMR-csoportban, az antitenzív terápia és az immunszuppresszív terápia minimális módosításával pedig a DSA-pozitív csoportban. A részletesebb elemzésben azonban azt látjuk, hogy az eGFRváltozás nem esik az ekvivalenciavonal alá, a fehérjeürítésnél azonban alatta helyezkednek el a mért értékek

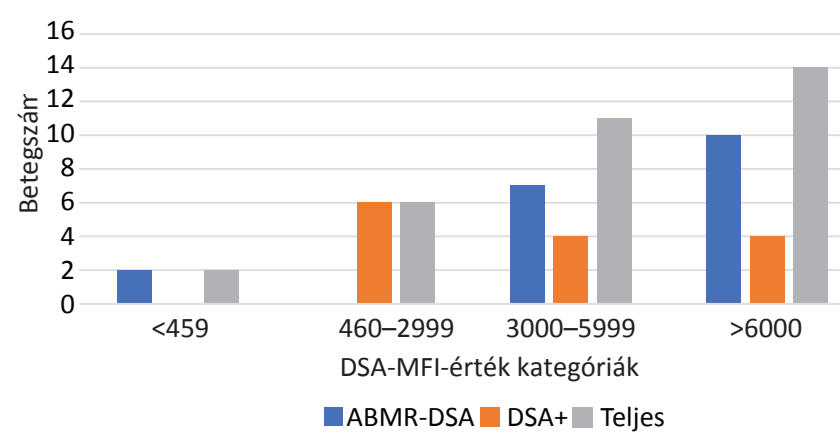

1. ábra $\quad$ DSA-MFI kategóriák az ABMR- és a DSA-pozitív csoportban A DSA-kat az MFI alapján alacsony, közepes és magas kockázati kategóriákba sorolják

$\mathrm{ABMR}=$ antitestmediált rejekció; DSA = donorspecifikus antitest; MFI = átlagos fluoreszcenciaintenzitás 


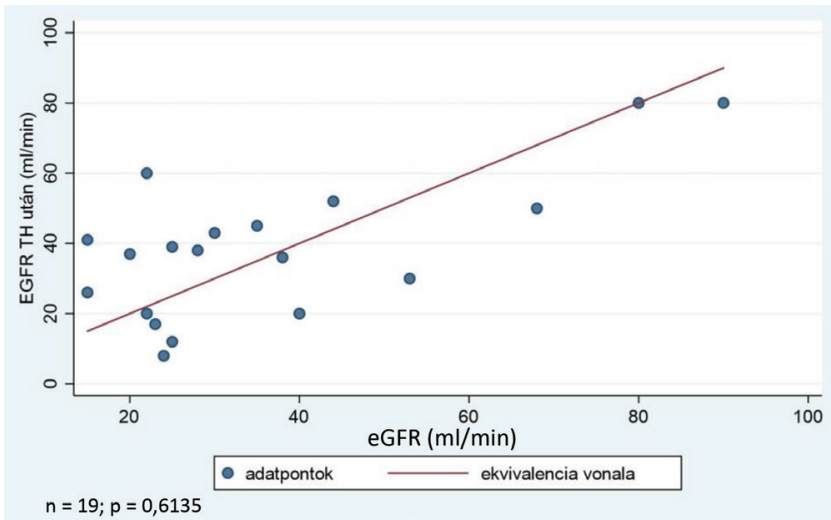

2/a ábra

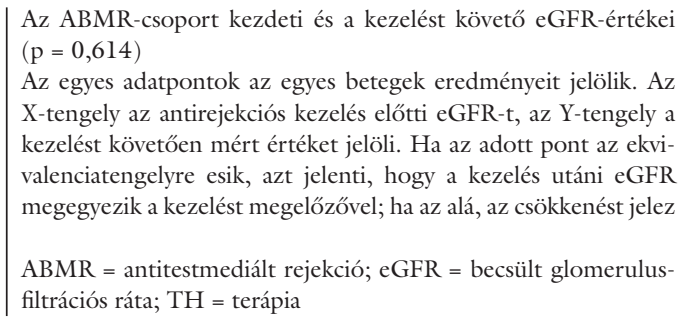

(2/a ábra). A terápia kezdetekor meglévő fehérjeürítés elemzésekor azt figyeltük meg, hogy az ABMR-csoportban 21\%-ban fordult elő nephroticus mértékú proteinuria, míg a DSA-pozitív csoportban 14,29\%-ban, a DSAnegatív csoportban 1,92\%-ban. Jelentős porteinuria (TPCR: 5l-350 közötti) 36\%-ban volt jelen az ABMR-, $28 \%$-ban a DSA-pozitív csoportban, de a stabil graftfunckió mellett is közel 20\%-ban fordult elő a DSA-ne-

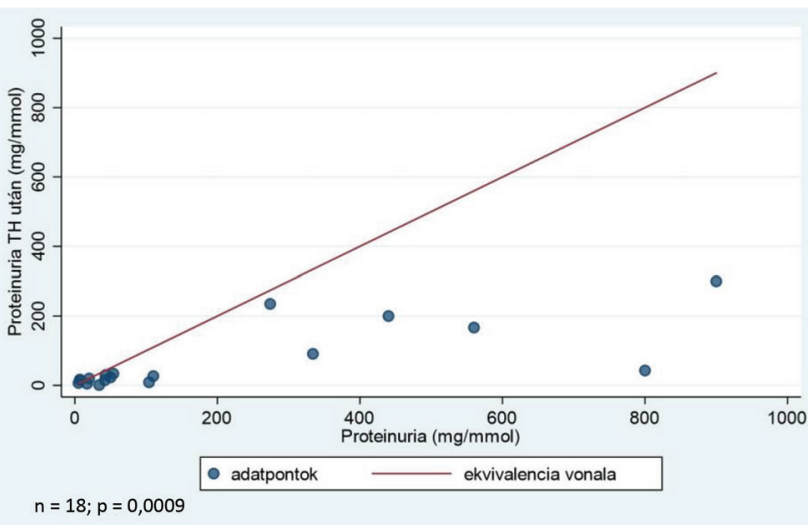

2/b ábra Az ABMR-csoport kezdeti és a kezelést követő fehérjeürítése $(\mathrm{p}<0,001)$

Az egyes adatpontok az egyes betegek eredményeit jelölik. Az $\mathrm{X}$-tengely az antirejekciós kezelés előtti, az Y-tengely a kezelést követően mért fehérjeürítés értékeit ábrázolja. Ha az adott pont az ekvivalenciatengelyre esik, azt jelenti, hogy a kezelés utáni proteinuria megegyezik a kezelést megelőzővel; ha az alá, az csökkenést jelez

$\mathrm{ABMR}=$ antitestmediált rejekció; $\mathrm{TH}=$ terápia

gatív csoportban is. A fehérjeürítés minden egyes 10 $\mathrm{mg} / \mathrm{mmol}$ emelkedésével a graftvesztés rizikója 7\%-kal emelkedik (hazard ratio: 1,07; 95\% CI: 1,023-1,125; $\mathrm{p}=0,004)$ a DSA-negatív csoportban, míg a DSA-pozitív csoportokban nem igazolható ez a hatás ezen a mintán $(2 / b$ ábra $)$. Vizsgáltuk a kezdeti és a terápiára bekövetkező fehérjeürítés-csökkenés mértékét az ABMR-csoportban, hiszen az ABMR kedvezőtlen graft-

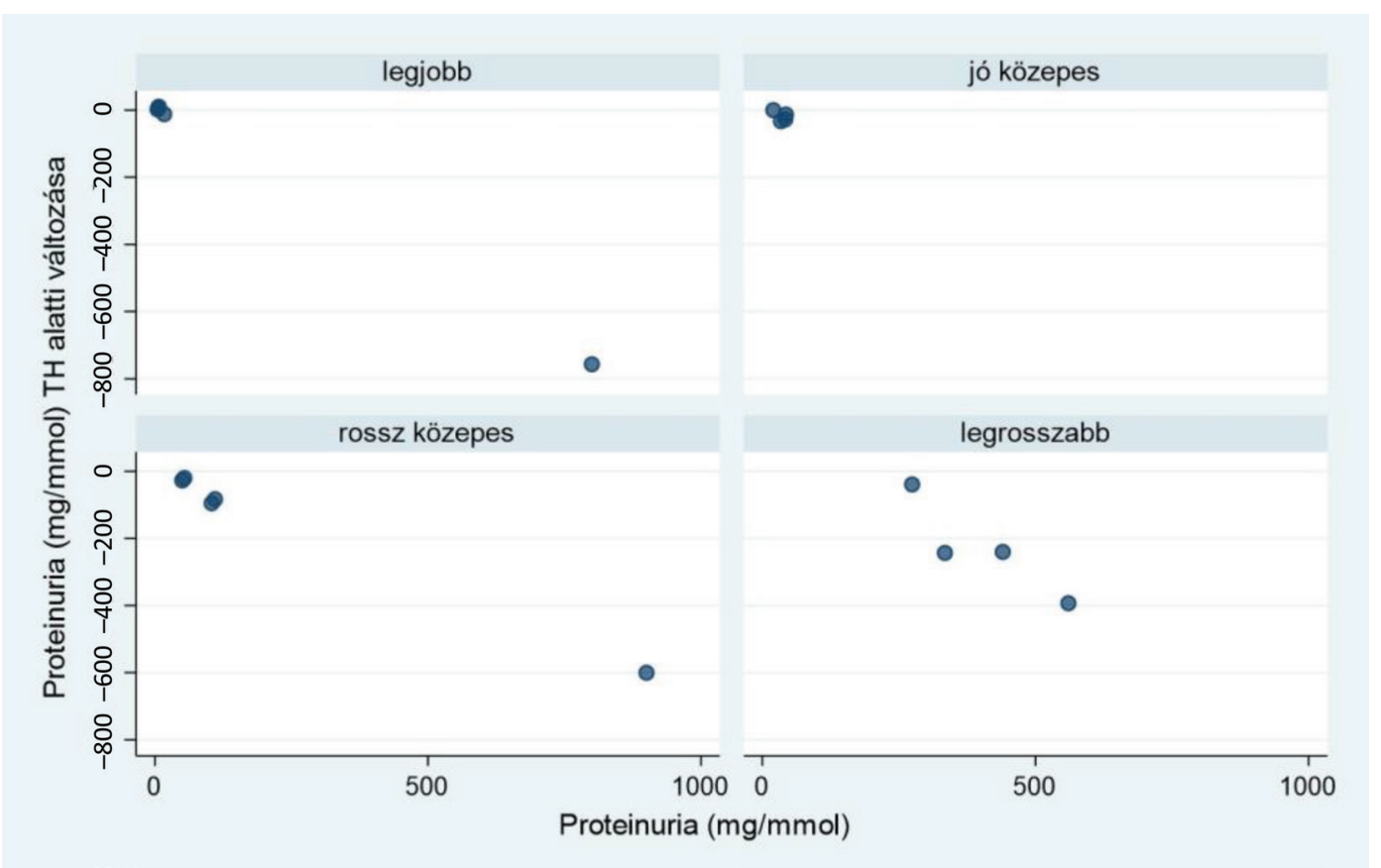

3. ábra $\quad$ A fehérjeürítés kezdeti értéke és a terápia alatti változása az ABMR-csoport grafttúlélés alapján képzett alcsoportjaiban

legjobb = a normoalbuminuriás csoport fehérjeürítés-mértéke $3 \mathrm{mg} / \mathrm{mmol}$ alatti; jó közepes = a microalbuminuriás ACR: 3-30 mg/mmol; rossz közepes = proteinuriás TPCR: $45-350 \mathrm{mg} / \mathrm{mmol}$; legrosszabb = nephroticus mértékú proteinuria, $>350 \mathrm{mg} / \mathrm{mmol}$

$\mathrm{ABMR}=$ antitestmediált rejekció; $\mathrm{ACR}=$ albumin-kreatinin arány, $\mathrm{TH}=$ terápia; $\mathrm{TPCR}$ = teljes protein-kreatinin arány 
prognózist jelent, és a fehérjeürítés vizsgálata egyszerü, könnyen ismételhető. Az ABMR-csoportban a legjobb grafttúlélés a legalacsonyabb proteinuria mellett jelentkezik, de azoknál is érzékelhető a kedvező hatás, akiknél kezdetben magas proteinuria állt fenn, és nagymértékben csökkent a terápia hatására. A legrosszabb túlélési negyedben vannak azok a betegek, akiknél kezdetben is magas érték volt, és ebből viszonylag kismértékben csökkent, ami szintén mutatja, hogy a fehérjeürítés (kezdeti + változás mértéke) és a grafttúlélés összefügg (3. ábra).

Az ABMR-rel rendelkező betegeink mintáiban microvascularis gyulladás volt megfigyelhető (Banff-pontszám: $1,7 ; 1,7 \pm 0,8)$ a kezelés előtt. 7 betegnél $(36 \%)$ IFTA került leírásra. Az ABMR a 19 betegból 3 esetben volt korai, azaz a transzplantációt követő 30 napon belüli, 16 esetben 30 napon túli. A betegek 36\%-a második vesetranszplantáción esett át: ők minden esetben timoglobulin indukciós kezelésben részesültek, mivel a preformált DSA-k miatt fokozott immunológiai rizikóval rendelkeztek. A biopsziás minták vizsgálata során csak a betegek 58\%-ánál észleltünk C4d-pozitivitást. Az ABMRcsoport betegeinek 15,77\%-ánál nem volt kimutatható DSA, és ennél az alcsoportnál egyúttal a C4d-negativitás is jellemző volt. A CD4-negatív ABMR-es betegünk szövettani változásai: a glomerulitis mértéke alapján a diagnóziskor Banff 2-es volt (kifejezett), a kezelés hatására l-es lett (enyhe forma), a glomerularis membrán kettőződési mértéke is csökkent, az arteriola hyalinosis enyhe formája viszont megjelent a kezelést követően. A grafttúlélés a vizsgált három csoportban az 4. ábrán látható. A becsült kumulatív 3 éves grafttúlélés az ABMR-csoportban $87,5 \%$, a DSA-pozitív csoportban 93\%, a DSAnegatív csoportban $100 \%$ volt (log-rank teszt: $\mathrm{p}=0,067)$.

\section{Megbeszélés}

Az ABMR a graftvesztés gyakori oka a vesetranszplantáltak körében. Kezelése költséges, ezért a megelőzésre fontos hangsúlyt kell fektetni a napi gyakorlatban. Mivel az ABMR egyik rizikófaktora a nem pontos gyógyszerszedés, az ismételt betegoktatással javítható a betegek együttmúködése, és ez preventív lépés. A COVID19-pandémia alatt a betegek gondozása nehézségekbe ütközik. A reguláris kontroll kötelező ritkulásával várható, hogy több antitestmediált humorális rejekciót kényszerülünk majd kezelni a közeljövőben. Nem elhanyagolható, hogy a terápiára adott válasz ténylegesen hogyan monitorizálható, követhető. Éppen emiatt célszerú a betegek ABMR-rizikójának becslése, a rizikócsoportok fokozott figyelme, beleértve a betegedukációt, az immunszuppresszió megfelelő adaptálását, mérlegelve az infekciós, illetve malignus betegségek, mellékhatások kialakulásának veszélyét és a betegek cardiovascularis rizikóját. A könnyen elérhető, kevésbé költséges fehérjeürítés rendszeres ellenőrzését javasoljuk a gondozás során, hiszen ezen egyszerü paraméter monitorizálásával és a megfelelő terápiás módosítással (ACE-gátlók, AA, sztatinok, normoglykaemiára való törekvés, a célhemoglobin elérése) a betegek cardiovascularis rizikója is csökkenthető [17-19]. A DSA-szúrés jól bejáratott módszer, Debrecenben is protokoll szerint végezzük [27]. Ez azonban költséges, a klinikai gyakorlatban történő interpretálása még sok új, megválaszolatlan kérdést generál, és nagyon magas MFI-érték esetén számolnunk kell az ún. „prozónahatás” torzító hatásával is. A DSA-vizsgálatok finomítása szintén költséges módszer, gondolva a Clq-kötő képességre, a nem HLA-ellenes antitestekre és az IgGalcsoportok szelektívebb vizsgálatára $[10,11]$. A vese-

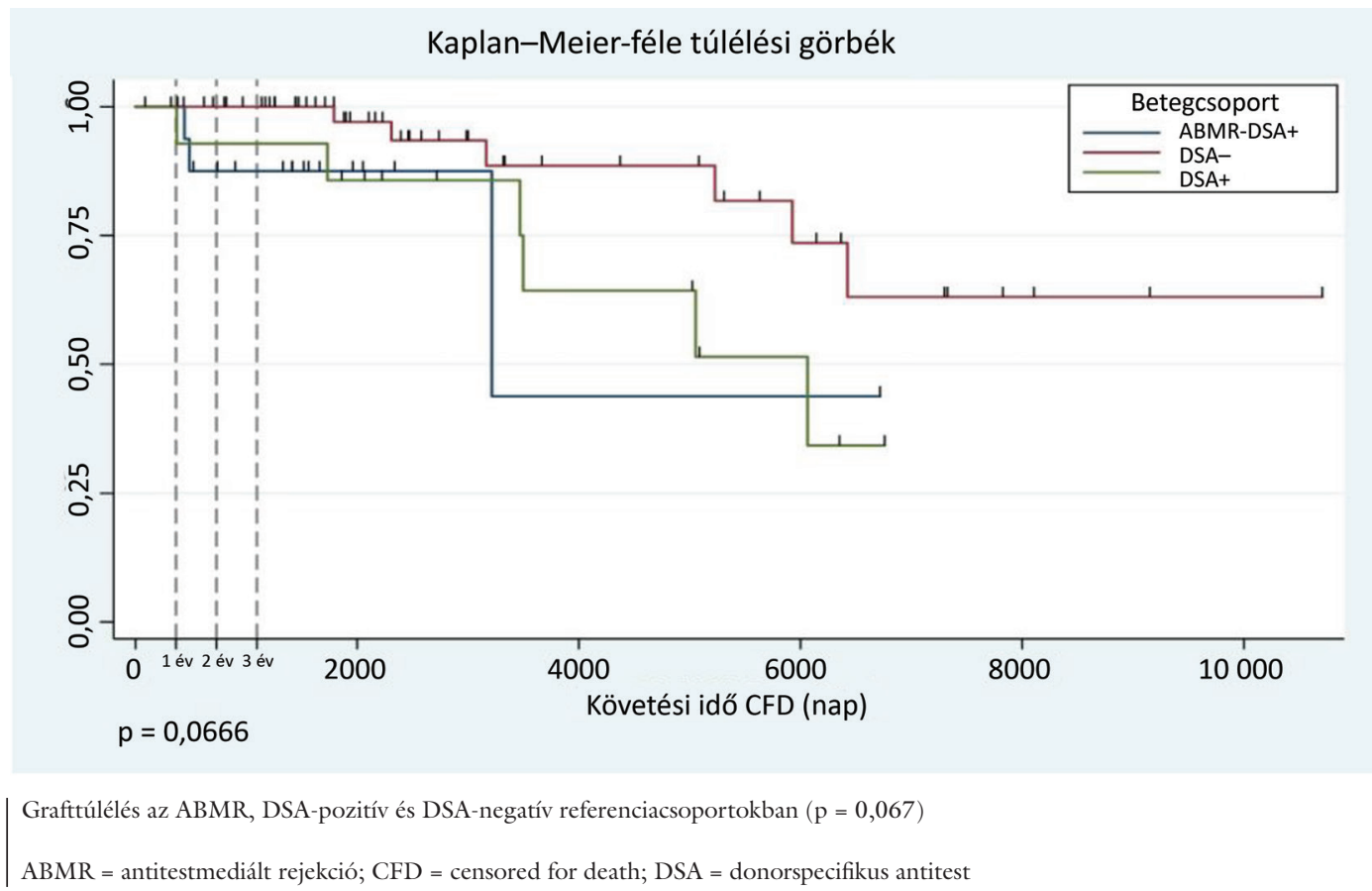


biopszia arany standard a diagnózis felállításához. Centrumunkban korábban gyakorlat volt a rendszeres nullbiopszia. Jelenleg ezt csak klinikailag releváns esetekben végezzük. A veseátültetés után 8-16 hónappal végzett „protokollbiopszia” hasznos lenne. Ez önkéntes beleegyezésen alapszik, és az invazivitás, illetve a feltételezett szövődményektől való félelem miatt a betegek közel egyharmada nem vállalja. Aktív betegoktatást végzünk ennek az ellenállásnak a feloldására.

Viglietti és munkacsoportja létrehozott egy prognosztikus dinamikus pontrendszert, melyben az antirejekciós terápiára adott választ is vizsgálják, beleértve az eGFRváltozást, a DSA-MFI-érték változását, a PTC Banff-értékét. Függvényüket külső és belső validálással is hitelesítették, ennek ellenére az ismételt biopszia invazivitása limitálta széles körű elterjedését a klinikai gyakorlatban [2]. Az ABMR-rel diagnosztizált betegek grafttúlélését hasonlítottuk össze centrumunkban, amihez referenciaként a DSA-negatív betegek, illetve a DSA-pozitív - de biopsziával nem igazolt ABMR-rel nem rendelkező - betegek grafttúlélését használtuk föl. A grafttúlélés a DSAval nem rendelkezőknél a legkedvezőbb. Az ABMR-csoportban a terápiára bekövetkező eGFR-változás nem volt szignifikáns, a fehérjeürítés viszont igen. A fehérjeürítés $10 \mathrm{mg} / \mathrm{mmol}$-onkénti csökkentésével a graftvesztési rizikót 7\%-kal tudtuk mérsékelni a DSA-negatív csoportban, a másik két csoportban nem volt szignifikáns a hatás. Modelleztük a kezdeti proteinuria hatását, ami azért fontos, mert a kezelés előtt csak ez látható - a terápia alatti proteinuriaváltozás nyilván nem -, ebból viszont tudunk prognosztizálni. A vizsgálati mintánkon a DSA-negatív csoport esetén igazolódott, hogy előrevetít valamit a kezdeti proteinuria. Emellett modelleztük a kezdeti proteinuriának és kezelés alatti változásának az összetett hatását szelektíven az ABMR-csoportban. Megfigyelésünk alapján, ha a kezdeti magas proteinuria érdemben csökken a terápia során, az a jobb túlélés jele; a DSA-MFI szignifikánsan magasabb tartományban volt kimutatható az ABMR-csoportban a DSA-val rendelkező stabil betegekhez képest. A becsült 3 éves grafttúlélés az ABMR-csoportban 87,5\%-nak, a DSA-pozitív csoportban 93\%-nak, a DSA-negatív csoportban 100\%-nak adódott; mindez alátámasztja, hogy a betegek rizikóbesorolása szükséges és indokolt, hiszen a magasabb rizikójú betegcsoportok fokozott figyelmet igényelnek ahhoz, hogy a rosszabb grafttúlélésen javítani lehessen. Az antirejekciós kezelést követően 3 betegünknél állt rendelkezésre rebiopsziás lelet, melyekben a krónikus szövettani elváltozások megjelenését láttuk; a kis esetszám miatt ezen eredményekból statisztikát nem számoltunk. A tendencia azonban megfigyelhető, hogy a diagnózis felállításakor a szövettanban leírt akut gyulladásos elváltozások jelentősen csökkennek, azonban krónikus elváltozások jelennek meg a kezelést követően. A biopsziás minták alapján a betegek 58\%-ában volt C4d-pozitivitás. 15,77\%-ban nem volt kimutatható DSA az ABMR-csoportban; ezen alcsoportban jellemző volt a C4d-negati- vitás is. Senev és munkacsoportja közlése alapján a HLA elleni DSA nélküli ABMR átmeneti formát jelöl kedvezőbb prognózissal [13]. A jövőben az esetszám emelkedésével tervezzük az ABMR-DSA-negatív és ABMRDSA-pozitív csoportok részletes analízisét, kiterjesztve a C4d-statusra [13].

\section{Következtetés}

Az ABMR diagnózisát követően indikált és sikeresen kivitelezett antirejekciós terápia hatására csökken a DSAMFI-érték és a proteinuria is. A DSA-modellek (DSAMFI-csökkenés a kezelést követően) azonban esetünkben kevésbé voltak szignifikánsak, mint a fehérjeürítés (kezdeti + változás) által jelzett javulás. A legjobb grafttúlélés a legalacsonyabb proteinuria mellett jelentkezik, de annál is érzékelhető a kedvező hatás, akinél kezdetben magas proteinuria állt fenn, és nagymértékben csökkent a terápia hatására. A legrosszabb túlélési negyedben vannak azok a betegek, akiknél a proteinuria mértéke már kezdetben is magas volt, és ez ráadásul csak kismértékben csökkent a terápia (antirejekciós + antihypertensiv terápia) hatására. Összegezve ez szintén mutatja, hogy a proteinuria (kezdeti + változás mértéke) korrelál a grafttúléléssel [26, 28]. A szövettani leletek elemzésekor az a tendencia figyelhető meg, hogy a diagnózis felállításakor a szövettanon leírt akut gyulladásos elváltozások jelentősen csökkennek az antirejekciós kezelés hatására, azonban krónikus elváltozások jelennek meg [2].

Anyagi támogatás: A jelen munka megírása, illetve a kapcsolódó kutatómunka külön anyagi támogatásban nem részesült.

Szerzői munkamegosztás: P. Sz. R.: A kutatás megtervezése, felügyelése, a közlemény megírása, a várólistán lévő betegek és a transzplantált betegek gondozása. Sz. A.: A HLA-ellenes DSA leletezése. Zs. L.: A transzplantált betegek utógondozása. N. B.: A kutatás felügyelése, vesetranszplantációk végzése. B. J.: Nefrológiai gondozás. K. N., A. J. H.: Adatgyűjtés. B. L.: Graft szövettani eredmények véleményezése. K. L.: Statisztikai elemzés. A cikk végleges változatát valamennyi szerző elolvasta és jóváhagyta.

Érdekeltségek: A szerzőknek nincsenek érdekeltségeik.

\section{Irodalom}

[1] Mertens I, Willems H, Van Loon E, et al. Urinary protein biomarker panel for the diagnosis of antibody-mediated rejection in kidney transplant recipients. Kidney Int Rep. 2020; 5: 14481458.

[2] Viglietti D, Loupy A, Aubert O, et al. Dynamic prognostic score to predict kidney allograft survival in patients with antibodymediated rejection. J Am Soc Nephrol. 2018; 29: 606-619. 
[3] Iványi B. Transplant capillaropathy and transplant glomerulopathy: ultrastructural markers of chronic renal allograft rejection. Nephrol Dial Transplant. 2003; 18: 655-660.

[4] Haas M, Loupy A, Lefaucheur C, et al. The Banff 2017 Kidney Meeting Report: revised diagnostic criteria for chronic active $\mathrm{T}$ cell-mediated rejection, antibody-mediated rejection, and prospects for integrative endpoints for next-generation clinical trials. Am J Transplant. 2018; 18: 293-307.

[5] Dobi D, Bodó Z, Kemény É, et al. Peritubular capillary basement membrane multilayering in early and advanced transplant glomerulopathy: quantitative parameters and diagnostic aspects. Virchows Arch. 2016; 469: 563-573.

[6] Lipták P, Kemény E, Morvay Z, et al. Peritubular capillary damage in acute humoral rejection: an ultrastructural study on human renal allografts. Am J Transplant. 2005; 5: 2870-2876.

[7] Mohan S, Palanisamy A, Tsapepas D, et al. Donor-specific antibodies adversely affect kidney allograft outcomes. J Am Soc Nephrol. 2012; 23: 2061-2071.

[8] Hidalgo LG, Sis B, Sellares J, et al. NK cell transcripts and NK cells in kidney biopsies from patients with donor-specific antibodies: evidence for NK cell involvement in antibody-mediated rejection. Am J Transplant. 2010; 10: 1812-1822.

[9] Loupy A, Lefaucheur C, Vernerey D, et al. Molecular microscope strategy to improve risk stratification in early antibodymediated kidney allograft rejection. J Am Soc Nephrol. 2014; 25: 2267-2277.

[10] Lefaucheur C, Loupy A, Hill GS, et al. Preexisting donor-specific HLA antibodies predict outcome in kidney transplantation. J Am Soc Nephrol. 2010; 21: 1398-1406.

[11] Böhmig GA, Kikic Z, Wahrmann M, et al. Detection of alloantibody-mediated complement activation: a diagnostic advance in monitoring kidney transplant rejection? Clin Biochem. 2016; 49: 394-403.

[12] Roufosse C, Simmonds N, Clahsen-van Groningen C, et al. A 2018 Reference Guide to the Banff Classification of Renal Allograft Pathology. Transplantation 2018; 102(11): 1795-1814. [Erratum: Transplantation 2018; 102(12): e497.]

[13] Senev A, Coemans M, Lerut E, et al. Histological picture of antibody-mediated rejection without donor-specific anti-HLA antibodies: clinical presentation and implications for outcome. Am J Transplant. 2019; 19: 763-780.

[14] Loupy A, Haas M, Roufosse C, et al. The Banff 2019 Kidney Meeting Report (I): updates on and clarification of criteria for $\mathrm{T}$ cell- and antibody-mediated rejection. Am J Transplant. 2020; 20: 2318-2331.

[15] Zhang Y, Briggs D, Lowe D, et al. A new data-driven model for post-transplant antibody dynamics in high risk kidney transplantation. Math Biosci. 2017; 284: 3-11.

[16] Callemeyn J, Ameye H, Lerut E, et al. Revisiting the changes in the Banff classification for antibody-mediated rejection after kidney transplantation. Am J Transplant. 2020 Dec 31. doi: 10.1111/ajt.16474. [Online ahead of print]
[17] Suárez Fernández ML, G-Cosío F. Causes and consequences of proteinuria following kidney transplantanation. Nefrologia 2011; 31: 404-414.

[18] Bertrand D, Gatault P, Jauréguy M, et al. Protocol biopsies in patients with subclinical de novo donor-specific antibodies after kidney transplantation: a multicentric study. Transplantation 2020; 104: 1726-1737.

[19] Bello KA, Hemmelgarn B, Lloyd A, et al. Associations among estimated glomerular filtration rate, proteinuria, and adverse cardiovascular outcomes. Clin J Am Soc Nephrol. 2011; 6: 14181426.

[20] V. Oláh A, Kappelmayer J, Nagy J, et al. Guidelines for laboratory medicine specialists to evaluate calculated GFR, albuminuria and proteinuria. [Ajánlás a számított GFR és az albuminuria, proteinuria vizsgálatára laboratóriumi szakemberek számára.] Hyperton Nephrol. 2012; 16: 69-71. [Hungarian]

[21] Ibis A, Akgül A, Ozdemir N, et al. Posttransplant proteinuria is associated with higher risk of cardiovascular disease and graft failure in renal transplant patients. Transplant Proc. 2009; 41: 1604 -1608 .

[22] Bailly E, Anglicheau D, Blancho G, et al. Prognostic value of the persistence of Clq-binding anti-HLA antibodies in acute antibody-mediated rejection in kidney transplantation. Transplantation 2018; 102: 688-698.

[23] Diena D, Messina M, Biase DC, et al. Relationship between early proteinuria and long term outcome of kidney transplanted patients from different decades of donor age. BMC Nephrol. 2019; 20: 443 .

[24] Matsushita K, Coresh J, Sang Y, et al. Estimated glomerular filtration rate and albuminuria for prediction of cardiovascular outcomes: a collaborative meta-analysis of individual participant data. Lancet Diabetes Endocrinol. 2015; 3: 514-525.

[25] Naesens M, Lerut E, Emonds MP, et al. Proteinuria as a noninvasive marker for renal allograft histology and failure: an observational cohort study. J Am Soc Nephrol. 2016; 27: 281-292.

[26] Halimi JM, Laouad I, Buchler M, et al. Early low-grade proteinuria: causes, short-term evolution and long-term consequences in renal transplantation. Am J Transplant. 2005; 5: 2281-2288.

[27] Nemes B, P. Szabó R, Bidiga L, et al. Antibody-mediated rejection: challenge of the treatment in kidney transplantated patients. [Antitestmediált rejekció: kihívás a veseátültetett betegek kezelésében.] Orv Hetil. 2018; 159: 1913-1929. [Hungarian]

[28] Eskandary F, Bond G, Kozakowski N, et al. Diagnostic contribution of donor-specific antibody characteristics to uncover late silent antibody-mediated rejection - results of a cross-sectional screening study. Transplantation 2017; 101: 631-641.

(P. Szabó Réka dr., Debrecen, Móricz Zs. krt. 22., 4032 e-mail: rpszabo@belklinika.com)

A cikk a Creative Commons Attribution 4.0 International License (https://creativecommons.org/licenses/by/4.0/) feltételei szerint publikált Open Access közlemény, melynek szellemében a cikk bármilyen médiumban szabadon felhasználható, megosztható és újraközölhető, feltéve, hogy az eredeti szerző és a közlés helye, illetve a CC License linkje és az esetlegesen végrehajtott módosítások feltüntetésre kerülnek. (SID_1) 